\title{
Assessments of Water-Soluble Inorganic Ions and Heavy Metals in Atmospheric Dustfall and Topsoil in Lanzhou, China
}

\author{
Yingquan Li ${ }^{1,2}$, Baowei Zhao ${ }^{1, *}$, Kaixiang Duan ${ }^{1}$, Juexian Cai ${ }^{1,2,3}$, Wujiang Niu ${ }^{4}$ \\ and Xiao Dong 2,3 \\ 1 School of Environmental and Municipal Engineering, Lanzhou Jiaotong University, Lanzhou 730070, China; \\ yingquanli@mail.lzjtu.cn (Y.L.); 022412125@hncj.edu.cn (K.D.); caijuexian@sina.com (J.C.) \\ 2 Gansu Dust Suppression for Transportation and Storage Engineering Research Center, \\ Lanzhou 730070, China; xiaodong_lztj@sina.com \\ 3 Lanzhou Tianji Environmental Protection Limited Company, Lanzhou 730070, China \\ 4 Environmental Monitoring Center Station in Gansu Province, Lanzhou 730020, China; \\ wujiangniu1958@sina.com \\ * Correspondence: zhbw2001@sina.com; Tel.: +86-931-4955760
}

Received: 10 March 2020; Accepted: 22 April 2020; Published: 24 April 2020

\begin{abstract}
The chemical features of atmospheric dustfall and topsoil in the same region could reflect the processes of the migration, transport, and diffusion of pollutants in the atmospheric-soil system. Samples of atmospheric dustfall and topsoil were collected in Lanzhou City. The contents and correlation of water-soluble inorganic ions (WSIIs) and heavy metals in dustfall and topsoil were analyzed, the sources of heavy metals and WSIIs in dustfall were distinguished, and the potential ecological risks of heavy metals in dustfall and topsoil were evaluated. The highest contents of WSIIs are $\mathrm{SO}_{4}{ }^{2-}\left(18,594 \mathrm{mg} \cdot \mathrm{kg}^{-1}\right)$ and $\mathrm{Ca}^{2+}\left(10,070 \mathrm{mg} \cdot \mathrm{kg}^{-1}\right)$ in dustfall, and for $\mathrm{SO}_{4}{ }^{2-}\left(8271 \mathrm{mg} \cdot \mathrm{kg}^{-1}\right)$ and $\mathrm{Na}^{+}\left(1994 \mathrm{mg} \cdot \mathrm{kg}^{-1}\right)$ in topsoil. The concentrations of heavy metals $(\mathrm{Pb}, \mathrm{Cu}, \mathrm{Zn}, \mathrm{Cr}, \mathrm{Cd}$, and $\mathrm{Ni})$ in dustfall are considerably higher than those in topsoil. Combustion of biomass and coal, transportation and industrial activities are the major anthropogenic sources of WSIIs and heavy metals in Lanzhou. Pollution of heavy metals except $\mathrm{Cr}$ and $\mathrm{Ni}$ in dustfall, and $\mathrm{Cu}, \mathrm{Cr}$, and $\mathrm{Ni}$ in topsoil was up to different degrees, where the pollution of $\mathrm{Cd}$ was serious. The risk of $\mathrm{Cd}$ in dustfall is high while moderate in topsoil. This research could offer a reference for the atmospheric particle pollution prevention and control in Lanzhou.
\end{abstract}

Keywords: dustfall; topsoil; water-soluble inorganic ions (WSIIs); heavy metals; contamination characteristics; Lanzhou

\section{Introduction}

Atmospheric dustfall is one of the main urban atmospheric particulate pollutants [1,2], and it has important environmental indication function [3]. As an indirect carrier, atmospheric dustfall brings pollutants from the atmosphere to the land surface or water, seriously affecting aquatic and terrestrial ecosystem [4]. With the continuous economic development and the urbanized advancement acceleration, the amounts of atmospheric dustfall and its carrying pollutants are increasing. As an important part of atmospheric particles, water-soluble inorganic ions (WSIIs) generally account for $20 \sim 60 \%$ of the mass concentration of particles [5,6], and even up to $80 \%$ [7]. WSIIs such as sulphate, nitrate, and ammonium are hygroscopic [6], which affect the visibility of atmosphere through the absorption and scattering of light [8]. They can also affect the acidity and alkalinity of atmospheric precipitation [9]. In addition, the atmospheric dustfall's contribution rate to the accumulation of heavy metals in topsoil ranks first among various exogenous input factors [10]. Heavy metal pollutants are not 
to be degraded and will cause long-term damage to human health and ecological environment [11,12]. Therefore, the study on the contamination features of WSIIs and heavy metals in the atmospheric dustfall and topsoil has become a research focus in environmental science field in recent years.

In 1975, Day et al. [13] first proposed the new term "city street dust fall." Since then, scholars have studied it in various aspects, including particle size characteristics [14], temporal distribution [15], spatial distribution [16], and chemical composition [17,18]. At present, the researches on WSIIs in atmospheric particles mainly focus on the analysis of pollution characteristics [6], source analysis [7], transformation mechanism between gaseous pollutants and WSIIs [19], and the effects on aerosol optical properties [8]. The researches on heavy metals in atmospheric particulates mainly focus on the heavy metal content [20], spatial distribution [21], pollution characteristics, source identification, ecological risk, and health risk assessment [22]. Currently, many studies on air particle pollution in China have paid close attention to the chemical composition, occurrence form, and source analysis. However, the research areas of both WSIIs and heavy metals in atmospheric particles are mostly concentrated in large and medium-sized cities or developed regions such as Beijing-Tianjin-Hebei region [23-25] and Yangtze River Delta [26]. There is very little research on atmospheric dustfall in arid and underdeveloped areas in the northwest China. Besides, analysis combining the data from heavy metals with WSIIs could provide interesting information, but there are few studies in this field.

Lanzhou is the capital of Gansu Province. It is located in the west of Loess Plateau and the Yellow River valley basin in the northeastern of Qinghai-Tibet Plateau, which is a typical "valley belt" city. The soil texture of Lanzhou is IV class self-weight collapsible loess, which is easy to produce dust pollution after human disturbance. The climate in this area is arid and the temperature inversion is serious in winter. The external input of sand dust from the surrounding deserts, a lot of smoke and dust emissions from industrial enterprises, exhausts from vehicles, and the continuous acceleration of construction results in a prominent PM contamination in Lanzhou City. Because of the special topography and climate, the atmospheric PM contamination pattern in Lanzhou may be different from those in other cities which are located in plain areas, for example, Beijing-Tianjin-Hebei region and Yangtze River Delta. Therefore, studying WSIIs and heavy metals in atmospheric dustfall and topsoil will be helpful to understand the regularities of their migration, transport, and diffusion in the atmospheric-soil system.

This article takes the main urban area of Lanzhou as the research area. The contents and correlation of WSIIs $\left(\mathrm{Cl}^{-}, \mathrm{F}^{-}, \mathrm{NO}_{2}{ }^{-}, \mathrm{NO}_{3}{ }^{-}, \mathrm{SO}_{4}{ }^{2-}, \mathrm{K}^{+}, \mathrm{Na}^{+}, \mathrm{Mg}^{2+}\right.$, and $\left.\mathrm{Ca}^{2+}\right)$ and heavy metals $(\mathrm{Pb}, \mathrm{Cu}, \mathrm{Zn}, \mathrm{Cr}, \mathrm{Cd}$, and $\mathrm{Ni}$ ) in dustfall and topsoil were studied. The sources of WSIIs and heavy metals in dustfall were distinguished. The potential ecological risks of heavy metals in dustfall and topsoil were evaluated, with an aim to supply a reference for the atmospheric particle pollution prevention and control in Lanzhou.

\section{Materials and Methods}

\subsection{Study Area and Sample Collection}

Lanzhou is located at the Yellow River Valley and surrounded by hills. In the south there are Gaolan mountain and other loess hills, with an altitude of 1700 2500 m, which are 180 1000 m higher than that of Lanzhou City; in the north there are Loess hills and low or middle mountains, with an altitude of about $1700 \mathrm{~m}$, which are about $180 \mathrm{~m}$ higher than that of Lanzhou City. The landform of the main urban area of Lanzhou City is erosion accumulation valley plain. The geological structure of Lanzhou City belongs to the middle uplift zone of Qilian in Kunlun-Qinling geosyncline fold system. Because the Yellow River runs through Lanzhou City, local groundwater is relatively rich. The groundwater in Lanzhou City is mainly loose rock pore phreatic water. Landslides, collapses, and debris flows are the main types of geological disasters in Lanzhou City. The average annual temperature is $10.3^{\circ} \mathrm{C}$. The annual average sunshine hours are 2446, the frost-free period is 180 days, and the average annual precipitation is $327 \mathrm{~mm}$, which mainly concentrate from June to September. It is an important industrial base and transportation hub in northwest China. The main urban areas of Lanzhou (Chengguan District, 
Anning District, Qilihe District, and Xigu District, excluding suburban counties) were selected as the research areas. The atmospheric dustfall and topsoil samples were obtained at each sample position. The sampling sites are shown in Figure 1.

The samples were collected in July 2017, and there was no rainfall during the week before the collection. The atmospheric dustfall was sampled at a height of 1.0 to $2.0 \mathrm{~m}$ (being close to the height of human respiratory tract exposure) using hairbrush to collect the dust on clean paper and transfer it into self-sealing bag. Sampling was kept away from the demolition, factories, and other areas that could cause local pollution. Four samples were collected at each position by the three-point mixed method, which means that three samples are collected at each sample point and mixed as one atmospheric dustfall sample. A total of 40 samples were obtained. Topsoil samples (depth 2-10 cm) were collected on the bare ground or green belt near the sampling points of atmospheric dustfall by the three-point mixed method, and a total of ten samples were obtained. Both the atmospheric dustfall samples and the topsoil samples were pretreated as follows: the branches, leaves, etc., in the sample were removed. The samples were laid in a beaker and dried in an oven (DZF-6020A, Shanghai Lichen Instrument Technology Co., Ltd., Shanghai, China) at $105^{\circ} \mathrm{C}$ for $3 \mathrm{~h}$, and then the samples were crushed and passed through 20 mesh and 200 mesh sieves for reserve. The quartering method was applied for sample weighting.

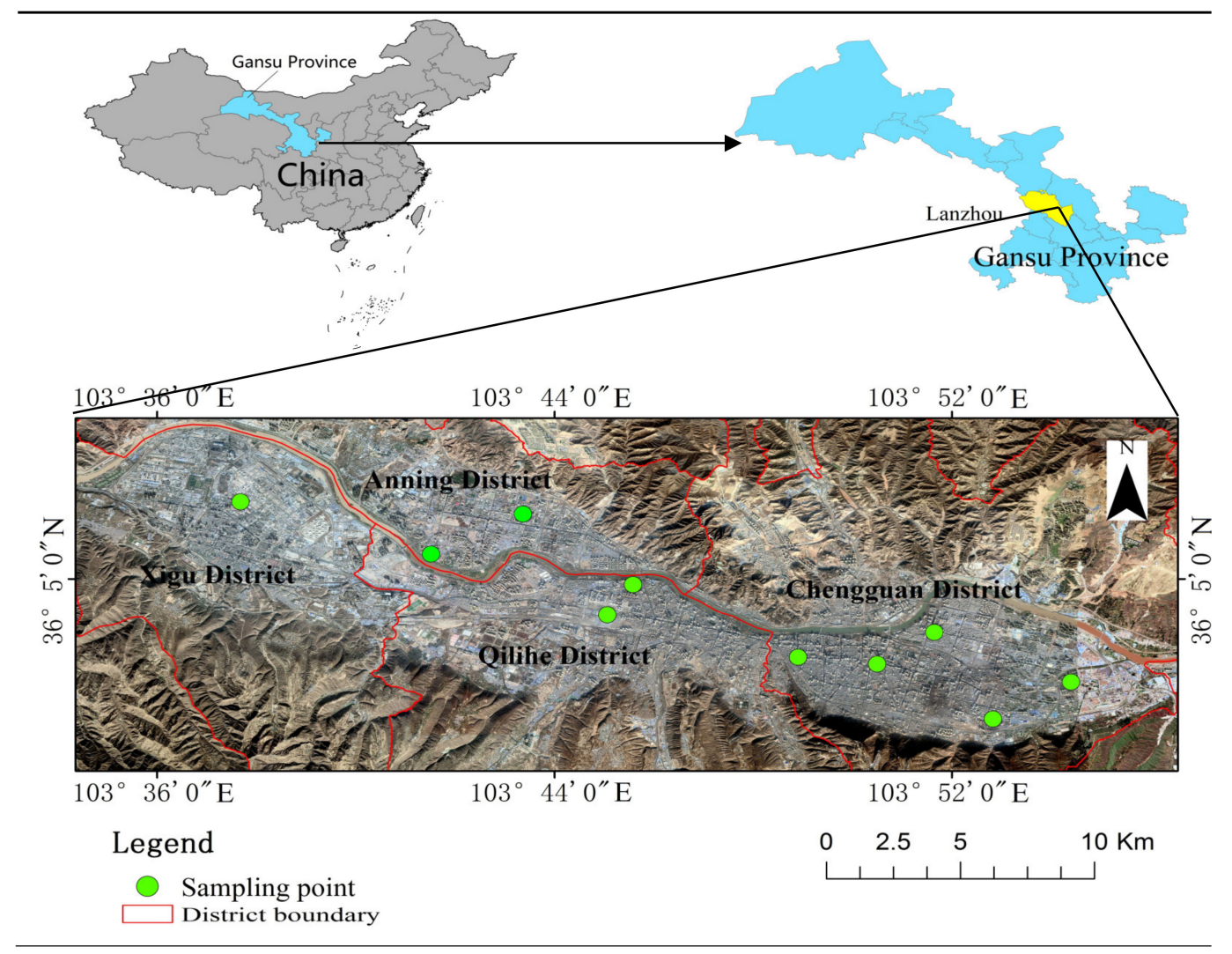

Figure 1. Study area and sampling sites.

\subsection{Materials}

The chemicals $\mathrm{NaF}, \mathrm{NaCl}, \mathrm{KNO}_{3}, \mathrm{NaNO}_{2}, \mathrm{NaNO}_{3}, \mathrm{Na}_{2} \mathrm{SO}_{4}, \mathrm{Mg}\left(\mathrm{NO}_{3}\right)_{2} \cdot 6 \mathrm{H}_{2} \mathrm{O}$, and $\mathrm{Ca}\left(\mathrm{NO}_{3}\right)_{2} \cdot 4 \mathrm{H}_{2} \mathrm{O}$ with superior grade purity, standard reserve solutions $\left(1000 \mathrm{mg} \cdot \mathrm{L}^{-1}\right)$ containing $\mathrm{Cl}^{-}, \mathrm{F}^{-}, \mathrm{NO}_{2}{ }^{-}, \mathrm{NO}_{3}{ }^{-}$, $\mathrm{SO}_{4}{ }^{2-}, \mathrm{Na}^{+}, \mathrm{K}^{+}, \mathrm{Mg}^{2+}$, and $\mathrm{Ca}^{2+}$, high purity argon (purity $\geq 99.999 \%$ ), standard reserve solutions of $\mathrm{Cu}, \mathrm{Zn}, \mathrm{Cr}, \mathrm{Cd}, \mathrm{Ni}, \mathrm{Pb}\left(1000 \mathrm{mg} \cdot \mathrm{L}^{-1}\right)$, internal standard solutions of $\mathrm{Rh}\left(10 \mu \mathrm{g} \cdot \mathrm{mL}^{-1}\right)$, mass spectrometry tuning solution (Be, In, $\mathrm{U}$, etc. $10 \mathrm{mg} \cdot \mathrm{L}^{-1}$ ), and the reagents $\mathrm{HNO}_{3}, \mathrm{HF}, \mathrm{HCl}, \mathrm{CH}_{4} \mathrm{~N}_{2} \mathrm{~S}$, and $\mathrm{H}_{2} \mathrm{O}_{2}$ with superior grade purity were bought from Baiyin Liangyou Chemical Reagents CO., LTD (Baiying, 
China). Soil for extractable trace elements (GBW07437, National Institute of Metrology, Beijing, China). Quality Control Materials (QCM-TW001 and QCM-CW001, Institute for Environmental Reference Materials of Ministry of Environmental Protection, Beijing, China). All standard solutions were prepared with ultrapure water (CSR-1-10, > 18.2 M $\cdot \cdot \mathrm{cm}$, Beijing ASTK Technology Development Co., Ltd., Beijing, China).

\subsection{Analytical Methods}

For ion determination, $0.1 \mathrm{~g}$ of sample was weighed placed into a $500-\mathrm{mL}$ centrifugal tube and $100 \mathrm{~mL}$ of ultrapure water was added. The tube cap was tightened, and ultrasonic extraction in water bath was conducted at $25{ }^{\circ} \mathrm{C}$ for $30 \mathrm{~min}$. The tube was rotated at $4000 \mathrm{r} \cdot \mathrm{min}^{-1}$ for $15 \mathrm{~min}$. The supernatant was taken and filtered through a $0.22-\mu \mathrm{m}$ membrane. All the samples were analyzed parallelly three runs with blank. Instead of weighing the sample, blank sample was prepared according to the same steps. WSIIs $\left(\mathrm{Cl}^{-}, \mathrm{F}^{-}, \mathrm{NO}_{2}{ }^{-}, \mathrm{NO}_{3}{ }^{-}, \mathrm{SO}_{4}{ }^{2-}, \mathrm{K}^{+}, \mathrm{Na}^{+}, \mathrm{Mg}^{2+}\right.$, and $\left.\mathrm{Ca}^{2+}\right)$ were determined by ion chromatograph (881 Compact IC pro, Metrohm, Herisau, Switzerland)). The detection limits of $\mathrm{Cl}^{-}, \mathrm{F}^{-}, \mathrm{NO}_{2}{ }^{-}, \mathrm{NO}_{3}{ }^{-}, \mathrm{SO}_{4}{ }^{2-}, \mathrm{K}^{+}, \mathrm{Na}^{+}, \mathrm{Mg}^{2+}$, and $\mathrm{Ca}^{2+}$ were $0.002,0.001,0.004,0.005,0.004,0.002$, $0.001,0.001$, and $0.003 \mathrm{mg} \cdot \mathrm{L}^{-1}$, respectively. The standard curve correlation coefficient was above 0.995 . The relative quasi-deviation of the three measurements was less than $9 \%$ and the recovery rates ranged from $86.0 \%$ to $89.7 \%$. The anion column was Metrosep A Supp 5-150 (Metrohm, Herisau, Switzerland). $3.2 \mathrm{mmol} \cdot \mathrm{L}^{-1} \mathrm{Na}_{2} \mathrm{CO}_{3}$ and $1 \mathrm{mmol} \cdot \mathrm{L}^{-1} \mathrm{NaHCO}_{3}$ were the eluent. The cationic column was Metrosep C4-150 (Metrohm, Herisau, Switzerland), and $5.6 \mathrm{mmol} \cdot \mathrm{L}^{-1} \mathrm{HNO}_{3}$ was the eluent.

As for heavy metal determination, a pretreatment was carried out for samples with an Automatic Digestion Instrument (Politech DigestLinc ST60D, Beijing, China). Total of $0.5 \mathrm{~g}$ of each sample was weighed and put into Teflon beaker, $10 \mathrm{~mL}$ of $\mathrm{HNO}_{3}-\mathrm{HCl}$ mixed solution $(167.5 \mathrm{~mL} \mathrm{HCl}$ and $55.5 \mathrm{~mL}$ $\mathrm{HNO}_{3}$ were added to $500 \mathrm{~mL}$ ultrapure water, with a constant volume up to $1 \mathrm{~L}$ ) was added. The beaker was covered and heated for $2 \mathrm{~h}$ at $100{ }^{\circ} \mathrm{C}$, then shaken well and cooled for $20 \mathrm{~min}$, diluted to $50 \mathrm{~mL}$ with ultrapure water, stood for $2 \mathrm{~h}$ and measured after filtration. Inductively coupled plasma mass spectrometry (ICP-MS X series II, Thermo Fisher Scientific (China) Co., Ltd., Shanghai, China) was used to determine the contents of metal elements. Soil for extractable trace elements (GBW07437) were selected as solid reference materials to draw working curve, which could basically eliminate the matrix interference in the determination of heavy metals in environmental soil by ICP-MS. Quality control materials (QCM-TW001 and QCM-CW001) were selected as reference solution for ICP-MS analysis. The standard curve correlation coefficient was above 0.9980 . The relative quasi-deviation of the three measurements was less than $10 \%$. The recovery rates are higher than $90 \%$.

\subsection{Assessment Methods}

Correlation analysis (CA) was used to characterize the variation rule of each element and the correlation degree among measured variables. The communality of each indicator was extracted by principal component analysis (PAC), then the compositional patterns were compared among the samples to find out the mutual influence factors. SPSS 22.0 software (IBM, New York, NY, USA) was used for PCA and CA.

Geo-accumulation index $\left(I_{\text {geo }}\right)$ is an index that reflects the effect of man-made activities and natural geological processes on heavy metal pollution $[27,28]$, and it is described by the Equation (1).

$$
I_{\text {geo }}=\log _{2}\left(\frac{C_{i}}{1.5 \times B_{i}}\right)
$$

where $B_{i}$ is the environmental background value in Gansu province [29], $C_{i}$ refers to the measured value of the metal $i .1 .5$ is a correction factor related to the geological and sedimentary characteristics of rocks. If $I_{\text {geo }} \leq 0$, it means the medium is uncontaminated; $0<I_{\text {geo }}<1$, from uncontaminated to moderately contaminated; $1<I_{\text {geo }}<2$, moderately contaminated; $2<I_{\text {geo }}<3$, from moderately to 
strongly contaminated; $3<I_{\text {geo }}<4$, strongly contaminated; $4<I_{\text {geo }}<5$, from strongly to extremely contaminated; and $I_{\text {geo }}>5$, extremely contaminated [30].

The degree of the potential environmental risk of heavy metals could reflect by potential ecological risk index $(R I)$, which is a comprehensive index that regards environmental effect, ecological effect, and toxicity [31].

$$
R I=\sum_{i=1}^{n} E_{r}^{i}=\sum_{i=1}^{n}\left(T_{r}^{i} \times \frac{C_{i}}{C_{0}}\right)
$$

where $E_{r}{ }^{i}$ means the single factor potential ecological risk index. $C_{i}$ refers to the measured value of heavy metal $i$ in the sample. $C_{0}$ means heavy metal $i$ environmental background value in Gansu province [29]. $T_{r}{ }^{i}$ is toxic response factor of a given element, which for $\mathrm{Zn}, \mathrm{Cr}, \mathrm{Cu}, \mathrm{Ni}, \mathrm{Pb}$, and $\mathrm{Cd}$ are 1, 2, 5, 5, 5, and 30, respectively [31]. On the basis of Hakanson's research, the single factor potential ecological risk is usually regarded as safety while $E_{r}{ }^{i}<40$, slight $40 \leq E_{r}{ }^{i}<80$, moderate $80 \leq E_{r}{ }^{i}<160$, considerable $160 \leq E_{r}{ }^{i}<320$, and high $E_{r}{ }^{i} \geq 320$. The comprehensive potential ecological risk is usually regarded as low while $R I<150$, moderate $150 \leq R I<300$, considerable $300 \leq R I<600$, and high $R I \geq 600$ [31].

\section{Results and Discussion}

\subsection{The Contents of WSIIs and Heavy Metals in Dustfall and Topsoil}

As illustrated in Table 1, the contents of $\mathrm{SO}_{4}{ }^{2-}$ and $\mathrm{Ca}^{2+}$ in dustfall are higher than those of other WSIIs, with an average content of 18,594 and $10,070 \mathrm{mg} \cdot \mathrm{kg}^{-1}$, respectively. $\mathrm{Ca}^{2+}$ is the main element of construction [32], and $\mathrm{SO}_{4}{ }^{2-}$ mainly comes from the secondary conversion of $\mathrm{SO}_{2}$ emitted from industrial coal and the direct emission of wet desulfurization from thermal power plants $[33,34]$. Therefore, the high content of $\mathrm{Ca}^{2+}$ may be associated with the current subway construction and more construction sites in Lanzhou. The high concentration of $\mathrm{SO}_{4}{ }^{2-}$ may be associated with burning in centralized heating stations and thermal power plants. The contents of $\mathrm{SO}_{4}{ }^{2-}$ and $\mathrm{Na}^{+}$in topsoil are higher than $\mathrm{n}$ those of other WSIIs, with the average content of 8271 and $1833 \mathrm{mg} \cdot \mathrm{kg}^{-1}$, probably because the soil type in the area is predominantly saline-alkaline soil [35]. In both dustfall and topsoil, the main WSIIs are $\mathrm{SO}_{4}{ }^{2-}, \mathrm{Na}^{+}, \mathrm{Ca}^{2+}, \mathrm{Cl}^{-}$, and $\mathrm{NO}_{3}{ }^{-}$. The contents of WSIIs in the dustfall are much higher than those in topsoil, which indicates that WSIIs in the dustfall are affected by human activities in addition to the natural sources in the nearby soil.

Table 1. The contents of water-soluble inorganic ions (WSIIs) in atmospheric dustfall and topsoil ( $\left.\mathrm{mg}^{\mathrm{kg}} \mathrm{kg}^{-1}\right)$.

\begin{tabular}{ccccccccccc}
\hline Sample & Value & $\mathbf{F}^{-}$ & $\mathbf{C l}^{-}$ & $\mathbf{N O}_{3}{ }^{-}$ & $\mathbf{N O}_{2}^{-}$ & $\mathbf{S O}_{4}{ }^{2-}$ & $\mathbf{N a}^{+}$ & $\mathbf{K}^{+}$ & $\mathbf{M g}^{\mathbf{2 +}}$ & $\mathbf{C a}^{\mathbf{2 +}}$ \\
\hline \multirow{5}{*}{ Dustfall } & Min & 109 & 457 & 192 & 31 & 9955 & 171 & 1255 & 19.3 & 648 \\
& Max & 816 & 3267 & 3366 & 397 & 31,615 & 21,937 & 102 & 812 & 12,028 \\
& Mean & 350 & 1728 & 1755 & 87.6 & 18,954 & 3698 & 668 & 491 & 10,070 \\
& SD & 195.8 & 796.1 & 965.2 & 43.8 & 7960.7 & 1664.1 & 374.1 & 176.8 & 3110 \\
& VC & 0.56 & 0.46 & 0.55 & 0.50 & 0.42 & 0.45 & 0.56 & 0.36 & 0.31 \\
\hline \multirow{5}{*}{ Topsoil } & Min & 8.15 & 29.7 & 13.3 & 1.95 & 60 & 16.2 & 42.5 & 0.708 & 7.98 \\
& Max & 39.8 & 2471 & 3375 & 54.8 & 31,634 & 12,202 & 386 & 353 & 9920 \\
& Mean & 18.4 & 747 & 694 & 16.2 & 8271 & 1994 & 193 & 165 & 1833 \\
& SD & 9.57 & 313.7 & 381.7 & 6.97 & 3391.1 & 1016.9 & 94.6 & 47.9 & 403.3 \\
& VC & 0.52 & 0.42 & 0.49 & 0.43 & 0.41 & 0.51 & 0.49 & 0.29 & 0.22 \\
\hline
\end{tabular}

"Min" is the minimum concentration of WSIIs in collected samples; "Max" is the maximum concentration of WSIIs in collected samples; "Mean" is the arithmetic mean concentration of WSIIs in all samples. "SD" is the standard deviation of samples. "VC" is the variation coefficient of samples.

Furthermore, the ratio of $\mathrm{NO}_{3}{ }^{-}$and $\mathrm{SO}_{4}{ }^{2-}$ in atmospheric particles is usually used to judge whether the city air is mainly polluted by flowing sources (such as automobile exhaust) or by stationary sources (such as coal burning) [36]. Ratios being greater than 1 and less than 1 represent flowing and 
stationary sources [36], respectively. The ratio of $\mathrm{NO}_{3}{ }^{-}$and $\mathrm{SO}_{4}{ }^{2-}$ in this study is 0.09 , indicating that atmospheric dustfall in Lanzhou is mainly from stationary sources.

The concentrations of heavy metals in atmospheric dustfall and topsoil are illustrated in Table 2. The average concentrations of heavy metals in atmospheric dustfall are in the order of $\mathrm{Zn}\left(379.84 \mathrm{mg} \cdot \mathrm{kg}^{-1}\right)$ $>\mathrm{Pb}\left(133.78 \mathrm{mg} \cdot \mathrm{kg}^{-1}\right)>\mathrm{Cr}\left(95.61 \mathrm{mg} \cdot \mathrm{kg}^{-1}\right)>\mathrm{Cu}\left(84.25 \mathrm{mg} \cdot \mathrm{kg}^{-1}\right)>\mathrm{Ni}\left(43.13 \mathrm{mg} \cdot \mathrm{kg}^{-1}\right)>\mathrm{Cd}\left(3.89 \mathrm{mg} \cdot \mathrm{kg}^{-1}\right)$. The similar results were observed by Li et al. [37]. The heavy metals average contents in topsoil are sorted from large to small as Zn $\left(136.07 \mathrm{mg} \cdot \mathrm{kg}^{-1}\right)>\mathrm{Cr}\left(85.25 \mathrm{mg} \cdot \mathrm{kg}^{-1}\right)>\mathrm{Pb}\left(55.99 \mathrm{mg} \cdot \mathrm{kg}^{-1}\right)>\mathrm{Cu}$ $\left(42.20 \mathrm{mg} \cdot \mathrm{kg}^{-1}\right)>\mathrm{Ni}\left(37.61 \mathrm{mg} \cdot \mathrm{kg}^{-1}\right)>\mathrm{Cd}\left(0.55 \mathrm{mg} \cdot \mathrm{kg}^{-1}\right)$, and the contents of $\mathrm{Zn}, \mathrm{Pb}, \mathrm{Cu}$ are slightly higher than those reported by Zhao et al. [38]. This may be related to the time accumulation effect of heavy metals in topsoil, and to some extent indicating that the pollution level of heavy metals in topsoil in Lanzhou is basically stable.

Table 2. The concentrations of heavy metals in atmospheric dustfall and topsoil in Lanzhou $\left(\mathrm{mg}^{\circ} \mathrm{kg}^{-1}\right)$.

\begin{tabular}{cccccccc}
\hline Sample & Value & $\mathbf{C u}$ & $\mathbf{P b}$ & $\mathbf{Z n}$ & $\mathbf{C r}$ & $\mathbf{C d}$ & $\mathbf{N i}$ \\
\hline \multirow{5}{*}{ Dustfall } & Min & 52.57 & 98.12 & 302.25 & 76.54 & 2.69 & 32.14 \\
& Max & 173.81 & 216.13 & 587.21 & 141.69 & 5.42 & 60.39 \\
& Mean & 84.25 & 133.78 & 379.84 & 95.61 & 3.89 & 43.13 \\
& SD & 35.03 & 33.96 & 80.44 & 18.54 & 0.89 & 8.74 \\
& VC & 0.42 & 0.29 & 0.25 & 0.19 & 0.23 & 0.20 \\
\hline \multirow{5}{*}{ Topsoil } & Min & 25.21 & 38.24 & 103.77 & 57.89 & 0.34 & 26.54 \\
& Max & 73.36 & 84.25 & 219.23 & 138.25 & 0.81 & 39.10 \\
& Mean & 42.20 & 55.99 & 136.07 & 85.25 & 0.55 & 37.61 \\
& SD & 14.79 & 16.80 & 32.66 & 17.91 & 0.14 & 7.52 \\
& VC & 0.35 & 0.30 & 0.24 & 0.21 & 0.25 & 0.12 \\
\hline
\end{tabular}

"Min" is the minimum concentration of heavy metals in collected samples; "Max" is the maximum concentration of heavy metals in collected samples; "Mean" is the arithmetic mean concentration of heavy metals in all samples. "SD" is the standard deviation of samples. "VC" is the variation coefficient of samples.

\subsection{Correlation Analysis of WSIIs and Heavy Metals}

Pearson correlation coefficient is a common way to determine the linear relationship between variables, and its value range is $-1 \sim 1$ [39]. The correlation analysis of ions could preliminarily infer the sources of different ions in dustfall and topsoil [23]. Correlation coefficients of WSIIs and heavy metals in dustfall and topsoil are illustrated in Tables 3 and 4.

As seen from Table 3, the same WSIIs in topsoil and dustfall are positively correlated, and the correlation degree is sorted from large to small as $\mathrm{Na}^{+}>\mathrm{SO}_{4}{ }^{2-}>\mathrm{Cl}^{-}>\mathrm{F}^{-}>\mathrm{Ca}^{2+}>\mathrm{NO}_{2}{ }^{-}>\mathrm{Mg}^{2+}>\mathrm{K}^{+}$ $>\mathrm{NO}_{3}{ }^{-}$, where the high correlation of $\mathrm{Na}^{+}$and $\mathrm{SO}_{4}{ }^{2-}$ with a correlation coefficient of 0.989 and 0.988 respectively is found $(P<0.01)$. It shows that there is a process of mutual migration and transformation of WSIIs in dustfall and topsoil, in which $\mathrm{Na}^{+}$and $\mathrm{SO}_{4}{ }^{2-}$ is more obvious. $\mathrm{F}^{-}$and $\mathrm{SO}_{4}{ }^{2-}$ in dustfull is significantly correlated with $\mathrm{Na}^{+}$and $\mathrm{NO}_{2}{ }^{-}$in topsoil respectively $(0.966$ and $0.991, P<0.01)$, and $\mathrm{Ca}^{2+}$ in dustfull is correlated with $\mathrm{Cl}^{-}(0.739), \mathrm{K}^{+}(0.779)$, and $\mathrm{Mg}^{2+}(0.786)$ in topsoil respectively $(P<0.05)$, which indicates that there is a good associated relationship between these indicators and their sources.

As illustrated in Table 4 . The correlation degree of selected heavy metal between topsoil and dustfall is reordered as $\mathrm{Cu}>\mathrm{Ni}>\mathrm{Zn}>\mathrm{Cd}>\mathrm{Cr}>\mathrm{Pb}$, being positively correlated, where the content of $\mathrm{Cu}$ has a high correlation coefficient of $0.943(P<0.01)$. It proves that heavy metals enter the topsoil through dustfall rather than the process of natural soil formation [40], in which it is more obvious for $\mathrm{Cu}$. $\mathrm{Cr}$ in dustfull is correlated with $\mathrm{Ni}$ in topsoil $(0.823, P<0.05)$, indicating they might be from a common source because of their good associated relationship. 
Table 3. Correlation coefficients of WSIIs in dustfull and topsoil.

\begin{tabular}{|c|c|c|c|c|c|c|c|c|c|}
\hline & $F^{-}(d)$ & $\mathrm{Cl}^{-}(\mathrm{d})$ & $\mathrm{NO}_{3}{ }^{-}(\mathrm{d})$ & $\mathrm{NO}_{2}{ }^{-}(\mathrm{d})$ & $\mathrm{SO}_{4}{ }^{2-}(\mathrm{d})$ & $\mathrm{Na}^{+}(\mathrm{d})$ & $\mathrm{K}^{+}(\mathrm{d})$ & $\mathrm{Mg}^{2+}(\mathrm{d})$ & $\mathrm{Ca}^{2+}(\mathrm{d})$ \\
\hline $\mathrm{F}^{-}(\mathrm{s})$ & 0.837 * & 0.241 & -0.101 & -0.434 & 0.607 & 0.663 & -0.353 & -0.392 & -0.230 \\
\hline $\mathrm{Cl}^{-}(\mathrm{s})$ & -0.160 & $0.882 *$ & 0.046 & -0.413 & 0.608 & -0.223 & -0.119 & 0.250 & 0.739 * \\
\hline $\mathrm{NO}_{3}{ }^{-}(\mathrm{s})$ & 0.020 & 0.413 & 0.105 & -0.433 & 0.744 & -0.027 & -0.145 & 0.204 & 0.652 \\
\hline $\mathrm{NO}_{2}^{-}(\mathrm{s})$ & 0.606 & 0.644 & 0.187 & 0.468 & $0.991^{* *}$ & 0.533 & -0.226 & -0.018 & 0.287 \\
\hline $\mathrm{SO}_{4}{ }^{2-}(\mathrm{s})$ & 0.576 & 0.568 & 0.090 & -0.546 & $0.988^{* *}$ & 0.527 & -0.325 & -0.099 & 0.239 \\
\hline $\mathrm{Na}^{+}(\mathrm{s})$ & $0.966^{* *}$ & 0.436 & 0.008 & -0.370 & 0.720 & $0.989 * *$ & -0.400 & -0.475 & -0.518 \\
\hline $\mathrm{K}^{+}(\mathrm{s})$ & -0.128 & 0.151 & -0.042 & -0.447 & 0.525 & -0.313 & 0.122 & 0.217 & 0.779 * \\
\hline $\mathrm{Mg}^{2+}(\mathrm{s})$ & -0.354 & 0.169 & 0.023 & -0.332 & 0.434 & -0.403 & -0.057 & 0.313 & 0.786 * \\
\hline $\mathrm{Ca}^{2+}(\mathrm{s})$ & -0.248 & 0.271 & 0.089 & -0.339 & 0.534 & -0.331 & -0.029 & 0.341 & 0.824 * \\
\hline
\end{tabular}

Table 4. Correlation coefficients of heavy metals in dustfull and topsoil.

\begin{tabular}{ccccccc}
\hline & $\mathbf{C u}(\mathbf{d})$ & $\mathbf{P b}(\mathbf{d})$ & $\mathbf{Z n}(\mathbf{d})$ & $\mathbf{C r}(\mathbf{d})$ & $\mathbf{C d}(\mathbf{d})$ & $\mathbf{N i ( d )}$ \\
\hline $\mathrm{Cu}(\mathrm{s})$ & $0.943^{* *}$ & -0.506 & 0.213 & 0.395 & -0.273 & 0.005 \\
$\mathrm{~Pb}(\mathrm{~s})$ & 0.201 & 0.052 & -0.103 & -0.116 & 0.252 & -0.605 \\
$\mathrm{Zn}(\mathrm{s})$ & 0.270 & -0.248 & $0.849 *$ & 0.564 & -0.188 & 0.273 \\
$\mathrm{Cr}(\mathrm{s})$ & -0.096 & -0.822 & -0.236 & 0.369 & -0.731 & 0.254 \\
$\mathrm{Cd}(\mathrm{s})$ & -0.528 & 0.273 & -0.720 & -0.595 & $0.725 *$ & -0.747 \\
$\mathrm{Ni}(\mathrm{s})$ & 0.125 & 0.556 & 0.649 & $0.823^{*}$ & -0.364 & $0.854{ }^{* *}$ \\
$* * p<0.01$ (2-tailed), ${ }^{*} p<0.05$ (2-tailed), (d and s represent dustfall and topsoil, respectively).
\end{tabular}

\subsection{The Sources of WSIIs and Heavy Metals}

Normally, it is difficult to distinguish sources precisely based on the results of CA, which means that further analysis needs to be carried out in combination with other methods. Principal component analysis (PCA) was implemented with normalized data. The suitability of the measured data was examined by Kaiser-Meyer-Olkin (KMO) test and Bartlett's test. The value of KMO test being larger than 0.5 indicates that PCA is effective [41]. In this work, the KMO and Bartlett's test value of WSIIs is 0.528 and 0 respectively, and the value of heavy metals is 0.560 and 0 respectively, which shows the PCA is valid [42]. A standard scoring function was exploited to distribute 0.1 to 1.0 points for each indicator [43]. The weights of every indicator is equal to the quotient of its communality and the sum of all indicators' communality [43]. Combining data from WSIIs and heavy metals in the same PCA analysis cloud provide important information which is missing when run the analysis separately. The content of WSIIs and heavy metals were extracted with three principal components (PC1, PC2, and PC3) based on the eigenvalue greater than 1. After the maximum orthogonal rotation of variance, a total of three factors are obtained (RPC1, RPC2, and RPC3), and the cumulative variance contribution rate are $88.64 \%$ (Table 5).

As seen from Table 5, RPC1 has a high loading of $\mathrm{F}^{-}, \mathrm{Cu}, \mathrm{Pb}, \mathrm{Zn}, \mathrm{Ni}$, and $\mathrm{Cr}$, and account for $39.93 \%$ of the total variance. RPC1 could be related to transportation and industrial production. It is reported that the fluorides that cause pollution mainly come from the processing industries such as bricks and tiles, cement, ceramics, electrolytic aluminum, and fluorine-containing drugs [44]. Because of the special geological characteristics of Lanzhou (more loess and limestone), there are more brick manufacturing industries in Lanzhou. Clay will escape calcium fluoride, silicon tetrafluoride, and hydrogen fluoride into the atmosphere during high-temperature sintering. In addition, there are aluminum manufacturing enterprises in Lanzhou. A large amount of gas such as hydrofluoric acid and silicon tetrafluoride and dust such as aluminum fluoride and calcium fluoride are generated during the electrolysis process. Cr mainly comes from soil, coal burning, and metal smelting [45]. However, there are few metal smelting enterprises and basically no garbage incineration in Lanzhou. Therefore, $\mathrm{Cr}$ is mainly related to coal burning in centralized heating stations and thermal power plants. The usual origins of $\mathrm{Pb}$ are industrial fumes, vehicle exhausts, sewage sludge, and lead arsenate pesticides [46]. However, in urban areas, pesticides are less used and sewage sludge is treated uniformly. Although the application of unleaded gasoline has reduced the content of $\mathrm{Pb}$ in per unit volume vehicle exhaust, it is 
believed that traffic source is still a considerable source of $\mathrm{Pb}$ in atmospheric environment of Lanzhou city due to the sharp increase of vehicles and the cumulative effect of $\mathrm{Pb}$ emissions from traffic sources in history. Some studies indicate that $\mathrm{Pb}$ extracted from vehicle exhausts does not diffuse significantly beyond $30 \mathrm{~m}$ from the road [47]. Coal burning exhausts, industrial fumes, and lead aerosols could be transferred long distances [48]. Atmospheric deposition is also a major source of $\mathrm{Pb}$. In addition, $\mathrm{Zn}$ and $\mathrm{Cu}$ are also commonly made into industrial products such as automobile parts [49]. Accordingly, $\mathrm{Zn}$ and $\mathrm{Cu}$ may come from transportation and industrial pollution. There are many Ni mines in Jinchang City, in the northwest of Lanzhou city, and the migration of aerosol is one of the factors for the existence of $\mathrm{Ni}$ in the study area.

RPC2 accounting for $32.39 \%$ of variables, are mainly related to WSIIs and affected by $\mathrm{Cl}^{-}, \mathrm{NO}_{3}{ }^{-}$, $\mathrm{NO}_{2}{ }^{-}, \mathrm{K}^{+}, \mathrm{Mg}^{2+}$, and $\mathrm{Ca}^{2+}$, which may be attributed to combustion and construction dust. $\mathrm{K}^{+}$and $\mathrm{Cl}^{-}$is associated with biomass combustion $[50,51], \mathrm{Ca}^{2+}$ and $\mathrm{Mg}^{2+}$ is used as an indicator of municipal construction [32], and $\mathrm{NO}_{3}{ }^{-}$and $\mathrm{NO}_{2}{ }^{-}$is mainly formed by the oxidation of nitrogen oxides produced by combustion [52]. According to RPC1, the sources of WSIIs in the atmospheric dustfall in Lanzhou are extensive and belong to compound pollution. Zhang et al. [53] analyzed and compared the aerosol samples from the same sampling point in winter of 1990 and 2007 in Lanzhou City, and found that the pollution type of WSIIs in Lanzhou City was "sulfuric acid calcium" type in 1990; the pollution type of air aerosol water soluble ions in Lanzhou City changed to multi-element direction in 2007. Zhao et al. [54] collected aerosol samples in Beijing from 2009 to 2010, analyzed the pollution characteristics of water-soluble ions in aerosols, and compared them with the relevant research results in Beijing several years ago. They found that the concentration of water-soluble secondary ions in $\mathrm{PM}_{2.5}$ in Beijing increased significantly, and the ratio of $\mathrm{NO}_{3}{ }^{-} / \mathrm{SO}_{4}{ }^{2-}$ increased significantly compared with that a few years ago, indicating that the pollution in Beijing has completely transformed from coal smoke pollution into a mixture of reactive gases and fine particles dominated by vehicle exhaust. Therefore, because of the development of regional economy, the change of industrial and energy structure and the increase of the number of motor vehicles, the proportion and order of the main WSIIs in atmospheric particulates could change obviously with the passage of time.

RPC 3 are responsible for $16.32 \%$ of the total variance and should represent natural source because of high loading of $\mathrm{SO}_{4}{ }^{2-}$ and $\mathrm{Na}^{+}$. The soil type in the study area is predominantly saline-alkaline soil, and the soil salt type is mainly $\mathrm{Na}_{2} \mathrm{SO}_{4}$ one [35].

Table 5. Principal component analysis (PCA) matrix of WSIIs and heavy metals.

\begin{tabular}{cccc}
\hline & \multicolumn{3}{c}{ Rotated Component Matrix } \\
\cline { 2 - 4 } Index & RPC1 & RPC2 & RPC3 \\
\hline $\mathrm{F}^{-}$ & 0.765 & 0.214 & 0.552 \\
$\mathrm{Cl}^{-}$ & 0.193 & 0.815 & 0.465 \\
$\mathrm{NO}_{3}{ }^{-}$ & 0.197 & 0.935 & 0.266 \\
$\mathrm{NO}_{2} \mathrm{SO}_{4}^{2-}$ & 0.271 & 0.752 & -0.236 \\
$\mathrm{Na}^{+}$ & 0.218 & 0.400 & 0.819 \\
$\mathrm{~K}^{+}$ & 0.064 & -0.126 & 0.905 \\
$\mathrm{Mg}^{2+}$ & 0.567 & 0.786 & -0.022 \\
$\mathrm{Ca}$ & 0.374 & 0.910 & 0.039 \\
$\mathrm{Cu}$ & 0.628 & 0.685 & 0.158 \\
$\mathrm{~Pb}$ & 0.928 & 0.174 & 0.321 \\
$\mathrm{Zn}$ & 0.818 & 0.435 & 0.005 \\
$\mathrm{Cr}$ & 0.966 & 0.186 & 0.169 \\
$\mathrm{Cd}$ & 0.652 & 0.356 & 0.085 \\
$\mathrm{Ni}$ & 0.856 & 0.378 & 0.272 \\
Contribution rate \% & 0.852 & 0.303 & -0.269 \\
\hline
\end{tabular}




\subsection{Contribution of Anthropogenic Heavy Metals}

The $I_{\text {geo }}$ values of heavy metals in atmospheric dustfall and topsoil are illustrated in Table 6. The pollution level of $\mathrm{Cd}$ in atmospheric dustfall ranges from strong to extreme, $\mathrm{Pb}$ from moderately to strongly, $\mathrm{Cu}$ and $\mathrm{Zn}$ moderately, and $\mathrm{Cr}$ and $\mathrm{Ni}$ uncontaminated. $\mathrm{Cd}$ pollution in the topsoil is moderate, $\mathrm{Pb}$ and $\mathrm{Zn}$ from uncontaminated to moderate, and $\mathrm{Cu}, \mathrm{Cr}$, and $\mathrm{Ni}$ uncontaminated. $\mathrm{Pb}$, $\mathrm{Zn}$, and $\mathrm{Cu}$ are called urban elements [55]. These three elements are highly enriched in atmospheric dustfall, while less concentrated in topsoil, indicating that $\mathrm{Pb}, \mathrm{Cu}$, and $\mathrm{Zn}$ elements in dustfall are primarily influenced by artificial activities, and their transport path is from atmosphere to soil. $\mathrm{Cd}$ is certain enrichment in both atmospheric dustfall and soil, and its transmission path may be that the atmosphere and soil influence each other.

Table 6. The $I_{\text {geo }}$ of heavy metals in atmospheric dustfall and topsoil in Lanzhou.

\begin{tabular}{ccccc}
\hline Sample & Heavy Metal & I $_{\text {geo }}$ Range & Mean & Pollution Degree \\
\hline \multirow{6}{*}{ Dustfall } & $\mathrm{Cu}$ & $0.5 \sim 2.3$ & 1.2 & Moderately \\
& $\mathrm{Pb}$ & $1.8 \sim 2.9$ & 2.2 & From moderately to strongly \\
& $\mathrm{Zn}$ & $1.6 \sim 2.5$ & 1.9 & Moderately \\
& $\mathrm{Cr}$ & $-0.5 \sim 0.4$ & -0.1 & Uncontaminated \\
& $\mathrm{Cd}$ & $3.9 \sim 4.9$ & 4.4 & From strongly to extremely \\
& $\mathrm{Ni}$ & $-0.7 \sim 0.2$ & -0.3 & Uncontaminated \\
\hline \multirow{6}{*}{ Topsoil } & $\mathrm{Cu}$ & $-0.5 \sim 1$ & 0.2 & Uncontaminated \\
& $\mathrm{Pb}$ & $0.4 \sim 1.6$ & 1.0 & From Uncontaminated to moderately \\
& $\mathrm{Zn}$ & $0 \sim 1.1$ & 0.4 & From Uncontaminated to moderately \\
& $\mathrm{Cr}$ & $-0.9 \sim 0.4$ & -0.3 & Uncontaminated \\
& $\mathrm{Cd}$ & $0.9 \sim 2.2$ & 1.6 & Moderately \\
& $\mathrm{Ni}$ & $-0.9 \sim-0.4$ & --0.5 & Uncontaminated \\
\hline
\end{tabular}

Liu et al. [56] evaluated the heavy metals Igeo in an industrial park of Shaanxi Province in spring, and found that Igeo values of heavy metals followed the order of $\mathrm{Cd}>\mathrm{Pb}>\mathrm{Zn}>\mathrm{Cu}>\mathrm{Cr}>\mathrm{Ni}$. Zhang et al. [57] studied the Igeo of various metal elements in the atmospheric dust in Quanzhou City, and found that $\mathrm{Ni}, \mathrm{Cu}, \mathrm{Zn}$, and $\mathrm{Pb}$ pollution is moderate; while $\mathrm{Cd}$ serious. It is suggested that $\mathrm{Cd}$ pollution is serious in dustfall in China cities, which should be paid more attention. Wang et al. [58] studied the $I_{g e o}$ of heavy metals in the air dust in the main urban area of Chongqing. They found that $\mathrm{Cd}$ is the most serious pollutant of the four heavy metals in dustfall, followed by $\mathrm{Pb}, \mathrm{Ni}$, and $\mathrm{Cr}$. The impact of atmospheric dust input on heavy metals in topsoil is not significant.

\subsection{Potential Ecological Risk}

The evaluation values of potential ecological risks of heavy metals in atmospheric dustfall and topsoil are illustrated in Table 7. The single factor ecological risk degree of $\mathrm{Cd}$ is high and moderate in the atmospheric dustfall and topsoil, respectively, and those of $\mathrm{Pb}, \mathrm{Zn}, \mathrm{Cu}, \mathrm{Cr}$, and $\mathrm{Ni}$ are safe. The comprehensive potential ecological risk degree is high and moderate in the atmospheric dustfall and topsoil, respectively, and is mainly caused by the high single factor ecological risk pollution degree of Cd. In general, the heavy metals in both atmospheric dustfall and topsoil of Lanzhou have certain potential ecological risks. The most seriously affected element is $\mathrm{Cd}$, which should be paid attention to by relevant departments. This is similar to studies in other parts of China, such as Chengdu, Taiyuan, and Tianjin, where the single factor ecological risk index of $\mathrm{Cd}$ is 8697,1203 , and 933 , respectively. The value of these several is far more than 520, the potential ecological risk is extremely strong [59]. Tian et al. [60] reported the $E_{r}{ }^{i}$ values of heavy metals in atmospheric dustfall in Nanjing were sorted as $\mathrm{Cd}(370.5)>\mathrm{Cu}(41.19)>\mathrm{Pb}(23.54)>\mathrm{Zn}(10.91)>\mathrm{Ni}(8.25)>\mathrm{Cr}$ (1.54). Chen et al. [61] found that the $E_{r}{ }^{i}$ of heavy metals in dustfall in Xi'an is $\mathrm{Cd}(1334)>\mathrm{Pb}(72.5)>\mathrm{Cu}(29.3)>\mathrm{Cr}(15.7)>\mathrm{Ni}(12.4)>$ $\mathrm{Zn}$ (10.4). Zhang et al. [57] observed that the average $E_{r}{ }^{i}$ of elements in dustfall in Quanzhou is Cd $(1402)>\mathrm{Pb}(32.87)>\mathrm{Cu}(27.40)>\mathrm{Ni}$ (24.38) $>\mathrm{Zn}$ (11.66) $>\mathrm{Cr}$ (6.16). Therefore, $\mathrm{Cd}$ has a very high 
potential ecological risk in atmospheric dustfall of various cities in China. Research by Li et al. [62] in Nanjing shows that atmospheric deposition has an obvious enrichment effect on heavy metals in the topsoil, which is affected by both the heavy metal content and the deposition amount of atmospheric deposition. The accumulation of some heavy metals in soil is closely related to atmospheric deposition.

Table 7. The average potential ecological risks of heavy metals in atmospheric dustfall and topsoil.

\begin{tabular}{cccccc}
\hline \multirow{2}{*}{ Type } & Metal & \multicolumn{2}{c}{$E_{r}{ }^{i}$} & \multicolumn{2}{c}{$\boldsymbol{R I}$} \\
\cline { 3 - 6 } & & Mean & Severity & Mean & Severity \\
\hline \multirow{5}{*}{ Dustfall } & $\mathrm{Cu}$ & 17.5 & safety & & \\
& $\mathrm{Pb}$ & 35.6 & safety & & \\
& $\mathrm{Zn}$ & 5.5 & safety & 1039.9 & High \\
& $\mathrm{Cr}$ & 2.7 & safety & & \\
& $\mathrm{Cd}$ & 972.5 & High & & \\
& $\mathrm{Ni}$ & 6.1 & safety & & \\
Topsoil & $\mathrm{Cu}$ & 8.7 & safety & & \\
& $\mathrm{Pb}$ & 14.9 & safety & & \\
& $\mathrm{Zn}$ & 2.0 & safety & 170.8 & Moderate \\
& $\mathrm{Cr}$ & 2.4 & safety & & \\
& $\mathrm{Cd}$ & 137.5 & Moderate & & \\
\hline & $\mathrm{Ni}$ & 5.3 & safety & & \\
\hline
\end{tabular}

$R I$ refers to the sum of potential ecological risk indexes of various elements.

\section{Conclusions}

WSIIs and heavy metals can have serious impacts on the ecological environment and human health. It is of great significance to study their pollution characteristics in the air-soil ecosystem. The results obtained in this work offer relevant information on the characteristic, sources, and level of WSIIs and heavy metals pollution in atmospheric dustfall and topsoil in Lanzhou. WSIIs have significant correlation with heavy metals. Combustion of biomass and coal, transportation and industrial activities are the major anthropogenic sources of WSIIs and heavy metals in the study area. In the process of pollution prevention, attention should be paid to controlling $\mathrm{Cd}$ because of its higher pollution index and potential ecological risks. This study could provide reference for the atmospheric particle pollution prevention and control in Lanzhou. In addition, the results of this study are helpful to understand the topsoil pollution in Lanzhou.

Author Contributions: Conceptualization, Y.L., B.Z., and W.N.; methodology, Y.L., W.N.; software, K.D., X.D.; formal analysis, Y.L., K.D.; investigation, Y.L., X.D.; resources, J.C.; data curation, X.D.; writing—original draft preparation, Y.L., K.D.; writing-review and editing, Y.L., B.Z.; supervision, B.Z.; funding acquisition, Y.L., J.C. All authors have read and agreed to the published version of the manuscript.

Funding: This research was financially supported by the Major Special Projects of the Ministry of Science and Technology of China (2016YFC020600), the Talent Innovation and Entrepreneurship Projects of Lanzhou (2018-RC-84) and the Young Scholars Science Foundation of Lanzhou Jiaotong University (2018033).

Conflicts of Interest: The authors declare no conflict of interest.

\section{References}

1. Vallack, H.W.; Shillito, D.E. Suggested guidelines for deposited ambient dust. Atmos. Environ. 1998, 32, $2737-2744$. [CrossRef]

2. Pan, Y.P.; Wang, Y.S. Atmospheric wet and dry deposition of trace elements at 10 sites in Northern China. Atmos. Chem. Phys. 2015, 15, 951-972. [CrossRef]

3. Han, Y.M.; Du, P.X.; Cao, J.J.; Posmentier, E.S. Multivariate analysis of heavy metal contamination in urban dusts of Xi'an, Central China. Sci. Total Environ. 2006, 355, 176-186. [CrossRef] 
4. He, Q.S.; Zhang, L.; Cui, Y.; Cheng, M.C.; Guo, L.L.; Liu, M.; Chen, L.G. Particle dry deposition of polycyclic aromatic hydrocarbons and its risk assessment in a typical coal-polluted and basin city, northern china. Atmos. Pollut. Res. 2017, 8, 1081-1089. [CrossRef]

5. Li, T.C.; Yuan, C.S.; Huang, H.C.; Lee, C.L.; Wu, S.P.; Tong, C. Clustered long-range transport routes and potential sources of $\mathrm{PM}_{2.5}$ and their chemical characteristics around the Taiwan Strait. Atmos. Environ. 2017, 148, 152-166. [CrossRef]

6. Wang, H.L.; Zhu, B.; Shen, L.J.; Xu, H.H.; An, J.L.; Xue, G.Q.; Cao, J.F. Water-soluble ions in atmospheric aerosols measured in five sites in the Yangtze river delta, China: Size-fractionated, seasonal variations and sources. Atmos. Environ. 2015, 123, 370-379. [CrossRef]

7. Huang, T.; Chen, J.; Zhao, W.T.; Cheng, J.X.; Cheng, S.G. Seasonal variations and correlation analysis of water-soluble inorganic ions in $\mathrm{PM}_{2.5}$ in Wuhan, 2013. Atmosphere 2016, 7, 49. [CrossRef]

8. Yue, D.L.; Zhong, L.J.; Zhang, T.; Shen, J.; Yuan, L.; Ye, S.Q.; Zhou, Y.; Zeng, L.M. Particle growth and variation of cloud condensation nucleus activity on polluted days with new particle formation: A case study for regional air pollution in the PRD region, China. Aerosol Air Qual. Res. 2016, 16, 323-335. [CrossRef]

9. Kerminen, V.M.; Hillamo, R.; Teinila, K.; Pakkanen, T.; Allegrini, I.; Sparapani, R. Ion balances of size-resolved tropospheric aerosol samples: Implications for the acidity and atmospheric processing of aerosols. Atmos. Environ. 2001, 35, 5255-5265. [CrossRef]

10. Nriagu, J.O. Changing Metal Cycles and Human Health, 1st ed.; Springer: Berlin/Heidelberg, Germany, 1984; pp. 113-141. [CrossRef]

11. Qiao, Q.Q.; Huang, B.C.; Zhang, C.X.; Piper, J.D.A.; Pan, Y.P.; Sun, Y. Assessment of heavy metal contamination of dustfall in northern China from integrated chemical and magnetic investigation. Atmos. Environ. 2013, 74, 182-193. [CrossRef]

12. Chen, B.; Stein, A.F.; Maldonado, P.G.; Sanchez de la Campa, A.M.; Gonzalez-Castanedo, Y.; Castell, N.; de la Fosa, J.D. Size distribution and concentrations of heavy metals in atmospheric aerosols originating from industrial emissions as predicted by the HYSPLIT model. Atmos. Environ. 2013, 71, 234-244. [CrossRef]

13. Day, J.P.; Hart, M.; Robinson, M.S. Lead in urban street dust. Nature 1975, 253, 343-345. [CrossRef]

14. Hassanvand, M.S.; Naddafi, K.; Faridia, S.; Arhami, M.; Naddafi, R.; Sowlat, M.H.; Pourpak, Z.; Rastkari, N.; Momeniha, F.; Kashani, H.; et al. Indoor/outdoor relationships of $\mathrm{PM}_{10}, \mathrm{PM}_{2.5}$, and $\mathrm{PM}_{1}$ mass concentrations and their water-soluble ions in a retirement home and a school dormitory. Atmos. Environ. 2014, 82, 375-382. [CrossRef]

15. Zhang, J.J.; Tong, L.; Huang, Z.W.; Zhang, H.L.; He, M.M.; Dai, X.R.; Zheng, J.; Xiao, H. Seasonal variation and size distributions of water-soluble inorganic ions and carbonaceous aerosols at a coastal site in Ningbo, China. Sci. Total Environ. 2018, 639, 793-803. [CrossRef] [PubMed]

16. Hao, T.Y.; Cai, Z.Y.; Chen, S.C.; Han, S.Q.; Yao, Q.; Fan, W.Y. Transport Pathways and Potential Source Regions of $\mathrm{PM}_{2.5}$ on the West Coast of Bohai Bay during 2009-2018. Atmosphere 2019, 10, 345. [CrossRef]

17. Wang, J.H.; Zhang, X.; Yang, Q.; Zhang, K.; Zheng, Y.; Zhou, G.H. Pollution characteristics of atmospheric dustfall and heavy metals in a typical inland heavy industry city in China. J. Environ. Sci. 2018, 71, 283-291. [CrossRef]

18. Zhang, J.Q.; Qu, C.K.; Qi, S.H.; Cao, J.J.; Zhan, C.L.; Xing, X.L.; Xiao, Y.L.; Zheng, J.R.; Xiao, W.S. Polycyclic aromatic hydrocarbons (PAHs) in atmospheric dustfall from the industrial corridor in Hubei Province, Central China. Environ. Geochem. Health 2015, 37, 891-903. [CrossRef]

19. Li, X.R.; Wang, L.L.; Wang, Y.S.; Wen, T.X.; Yang, Y.J.; Zhao, Y.N.; Wang, Y.F. Chemical composition and size distribution of airborne particulate mattes in Beijing during the 2008 Olympics. Atmos. Environ. 2012, 50, 278-286. [CrossRef]

20. Gao, J.J.; Tian, H.Z.; Cheng, K.; Lu, L.; Wang, Y.X.; Wu, Y.; Zhu, C.Y.; Liu, K.Y.; Zhou, J.R.; Liu, X.G.; et al. Seasonal and spatial variation of trace elements in multi-size airborne particulate matters of Beijing, China: Mass concentration, enrichment characteristics, source apportionment, chemical speciation and bioavailability. Atmos. Environ. 2014, 99, 257-265. [CrossRef]

21. Tang, R.L.; Ma, K.M.; Zhang, Y.X.; Mao, Q.Z. The spatial characteristics and pollution levels of metals in urban street dust of Beijing, China. Appl. Geochem. 2013, 35, 88-98. [CrossRef]

22. Safiur Rahman, M.; Khan, M.D.H.; Jolly, Y.N.; Kabir, J.; Akter, S.; Salam, A. Assessing risk to human health for heavy metal contamination through street dust in the Southeast Asian Megacity: Dhaka, Bangladesh. Sci. Total Environ. 2019, 660, 1610-1622. [CrossRef] [PubMed] 
23. Tian, Y.Z.; Shi, G.L.; Han, S.Q.; Zhang, Y.F.; Feng, Y.C.; Liu, G.R.; Gao, L.J.; Wu, J.H.; Zhu, T. Vertical characteristics of levels and potential sources of water-soluble ions in $\mathrm{PM}_{10}$ in a Chinese megacity. Sci. Total Environ. 2013, 447, 1-9. [CrossRef] [PubMed]

24. Huang, X.J.; Liu, Z.R.; Zhang, J.K.; Wen, T.X.; Ji, D.S.; Wang, Y.S. Seasonal variation and secondary formation of size-segregated aerosol water-soluble inorganic ions during pollution episodes in Beijing. Atmos. Res. 2016, 168, 70-79. [CrossRef]

25. Zhang, Y.Y.; Lang, J.L.; Cheng, S.Y.; Li, S.Y.; Zhou, Y.; Chen, D.S.; Zhang, H.Y.; Wang, H.Y. Chemical composition and sources of $\mathrm{PM}_{1}$ and $\mathrm{PM}_{2.5}$ in Beijing in autumn. Sci. Total Environ. 2018, 630, 72-82. [CrossRef] [PubMed]

26. Wang, J.; Zhang, Y.F.; Feng, Y.C.; Zheng, X.J.; Jiao, L.; Hong, S.M.; Shen, J.D.; Zhu, T.; Ding, J.; Zhang, Q. Characterization and source apportionment of aerosol light extinction with a coupled model of CMB-IMPROVE in Hangzhou, Yangtze River Delta of China. Atmos. Res. 2016, 178-179, 570-579. [CrossRef]

27. Müller, G. Index of geoaccumulation in sediments of the Rhine River. Geojournal 1969, 2, 108-118.

28. Wang, L.F.; Yang, L.Y.; Kong, L.H.; Li, S.; Zhu, J.R.; Wang, Y.Q. Spatial distribution, source identification and pollution assessment of metal content in the surface sediments of Nansi Lake, China. J. Geochem. Explor. 2014, 140, 87-95. [CrossRef]

29. Wu, S.D. The Atlas of Soil Environmental Background Value in the People's Republic of China, 1st ed.; China Environmental Science Press: Beijing, China, 1994; pp. 26-47.

30. Marrugo-Negrete, J.; Pinedo-Hernández, J.; Díez, S. Assessment of heavy metal pollution, spatial distribution and origin in agricultural soils along the Sinu River basin, Colombia. Environ. Res. 2017, 154, 380-388. [CrossRef]

31. Håkanson, L. An ecological risk index for aquatic pollution control: A sedimentological approach. Water Res. 1980, 14, 975-1001. [CrossRef]

32. Zhang, X.Y.; Cao, J.J.; Li, L.M.; Arimoto, R.; Cheng, Y.; Huebert, B.; Wang, D. Characterization of atmospheric aerosol over Xian in the south margin of the Loess plateau, China. Atmos. Environ. 2002, 36, 4189-4199. [CrossRef]

33. Zhou, J.B.; Xing, Z.Y.; Deng, J.J.; Du, K. Characterizing and sourcing ambient $\mathrm{PM}_{2.5}$ over key emission regions in China I: Water-soluble ions and carbonaceous fractions. Atmos. Environ. 2016, 135, 20-30. [CrossRef]

34. Liu, B.S.; Wu, J.H.; Zhang, J.Y.; Wang, L.; Yang, J.M.; Liang, D.N.; Dai, Q.L.; Bi, X.H.; Feng, Y.C.; Zhang, Y.F.; et al. Characterization and source apportionment of $\mathrm{PM}_{2.5}$, based on error estimation from EPA PMF 5.0 model at a medium city in China. Environ. Pollut. 2017, 222, 10-22. [CrossRef] [PubMed]

35. Gong, Z.T.; Chen, Z.C. Chinese Soil Taxonomy, 1st ed.; The Science Publishing Company: Beijing, China, 1999; pp. 382-416.

36. Yao, X.H.; Chan, C.K.; Fang, M.; Cadle, S.; Chan, T.; Mulawa, P.; He, K.B.; Ye, B.M. The water-soluble ions composition of $\mathrm{PM}_{2.5}$ in Shanghai and Beijing, China. Atmos. Environ. 2002, 36, 4223-4234. [CrossRef]

37. Li, P.; Xue, S.Y.; Wang, S.L.; Nan, Z.R. Pollution evaluation and health risk assessment of heavy metals from atmospheric deposition in Lanzhou. Environ. Sci. 2014, 35, 1021-1028. [CrossRef]

38. Zhao, C.C.; Nan, Z.R.; Wang, S.L.; Zeng, J.J.; Liu, J.; Jin, W.Q. Spatial distribution and pollution assessment of heavy metals in soil of main districts of Lanzhou City. Urban Environ. Urban Ecol. 2010, 23, 5-8.

39. Kraft, J.; Kraft, A. On the relationship between energy and GNP. J. Energy Dev. 1978, 3, 401-403. [CrossRef]

40. Huang, C.L.; Song, J.Q.; Pan, W.F. Impact of dry and wet atmospheric deposition on content of heavy metals in soils along coastal areas of eastern Zhejiang Province. Geol. Bull. China 2011, 30, 1434-1441.

41. Parinet, B.; Lhote, A.; Legube, B. Principal component analysis: An appropriate tool for water quality evaluation and management-application to a tropical lake system. Ecol. Model. 2004, 178, 295-311. [CrossRef]

42. Varol, M. Assessment of heavy metal contamination in sediments of the Tigris River (Turkey) using pollution indices and multivariate statistical techniques. J. Hazard. Mater. 2011, 195, 355-364. [CrossRef]

43. Cheng, J.J.; Ding, C.F.; Li, X.G.; Zhang, T.L.; Wang, X.X. Soil quality evaluation for navel orange production systems in central subtropical China. Soil Tillage Res. 2016, 155, 225-232. [CrossRef]

44. Pernigotti, D.; Belis, C.A.; Spanò, L. SPECIEUROPE: The European data base for PM source profiles. Atmos. Pollut. Res. 2016, 7, 307-314. [CrossRef]

45. Cheng, H.G.; Zhou, T.; Li, Q.; Lu, L.; Lin, C.Y. Anthropogenic chromium emissions in China from 1990 to 2009. PLoS ONE 2014, 9, e87753. [CrossRef] [PubMed] 
46. Franco-Uría, A.; López-Mateo, C.; Roca, E.; Fernández-Marcos, M.L. Source identification of heavy metals in pastureland by multivariate analysis in NW Spain. J. Hazard. Mater. 2009, 165, 1008-1015. [CrossRef] [PubMed]

47. Smith, W.H. Lead contamination of the roadside ecosystem. J. Air Pollut. Control Assoc. 1976, 26, 753-766. [CrossRef] [PubMed]

48. Facchinelli, A.; Sacchi, E.; Mallen, L. Multivariate statistical and GIS-based approach to identify heavy metal sources in soils. Environ. Pollut. 2001, 114, 313-324. [CrossRef]

49. Charlesworth, S.; Everett, M.; McCarthy, R.; Ordóñez, A.; De Miguel, E. A comparative study of heavy metal concentration and distribution in deposited street dusts in a large and a small urban area: Birmingham and Coventry, West Midlands, UK. Environ. Int. 2003, 29, 563-573. [CrossRef]

50. Zhao, J.P.; Zhang, F.W.; Xu, Y.; Chen, J. Characterization of water-soluble inorganic ions in size-segregated aerosols in coastal city, Xiamen. Atmos. Res. 2011, 99, 546-562. [CrossRef]

51. Dai, Q.L.; Bi, X.H.; Liu, B.S.; Li, L.W.; Ding, J.; Song, W.B.; Bi, S.Y.; Schulze, B.C.; Song, C.B.; Wu, J.H.; et al. Chemical nature of $\mathrm{PM}_{2.5}$ and $\mathrm{PM}_{10}$ in $\mathrm{Xi}$ 'an, China: Insights into primary emissions and secondary particle formation. Environ. Pollut. 2018, 240, 155-156. [CrossRef]

52. Elliott, S.; Shen, M.; Blake, D.R.; Lu, R.; Russell, A.G.; Kao, C.Y.J.; Streit, G.E.; Zhao, X.P.; Mccreary, E.I.; Sherwood Rowland, F.; et al. Atmospheric effects of the emerging mainland Chinese transportation system at and beyond the regional scale. J. Atmos. Chem. 1997, 27, 31-70. [CrossRef]

53. Zhang, N.; Li, L.P.; Dong, J.Y.; Li, L. Comparative study of water-soluble ions in atmospheric aerosols in Lanzhou in winters of 1990 and 2007. Res. Environ. Sci. 2010, 23, 647-652.

54. Zhao, P.S.; Zhang, X.L.; Meng, W.; Yang, B.Y.; Fan, W.Y.; Liu, H.Y. Characteristics of inorganic water-soluble ions from aerosols in Beijing-Tianjin-Hebei aerosol. Environ. Sci. 2011, 32, 1546-1549.

55. De Miguel, E.; Llamas, J.F.; Chacón, E.; Berg, T.; Larssen, S.; Røyset, O.; Vadset, M. Origin and patterns of distribution of trace elements in street dust: Unleaded petrol and urban lead. Atmos. Environ. 1997, 31, 2733-2740. [CrossRef]

56. Liu, J.; Gao, M.; Liang, J.N.; Chen, J. Characteristics and assessment of heavy metal pollution in spring atmospheric dust of an industrial park in Shaanxi Province. Res. Environ. Sci. 2019, 32, 1195-1203. [CrossRef]

57. Zhang, Z.W.; Hu, G.R.; Yu, R.L.; Liu, X.R.; Hu, Q.C.; Wang, X.M. Characteristics and source apportionment of metals in the dustfall of Quanzhou City. Environ. Sci. 2016, 37, 2881-2888. [CrossRef]

58. Wang, J.; Liu, B.; Xiao, B.L.; Li, Y.J.; Zhang, T.S.; Wu, H.; Zhang, Y.T. Characteristics of heavy metals in atmospheric deposition and its impact on their accumulation in soil of Chongqing. Soils 2019, 51, 1160-1167. [CrossRef]

59. He, R.D.; Zhang, Y.S.; Chen, Y.Y.; Jin, M.J.; Han, S.J.; Zhao, J.S.; Zhang, R.Q.; Yan, Q.S. Heavy metal pollution characteristics and ecological and health risk assessment of atmospheric $\mathrm{PM}_{2.5}$ in a living area of Zhengzhou City. Environ. Sci. 2019, 40, 4774-4782. [CrossRef]

60. Tian, C.H.; Yang, R.Z.; Gulizhaer, Y.; Qian, X.; Wang, J.H.; Li, H.M. Pollution levels and risk assessment of heavy metals from atmospheric deposition in Nanjing. Environ. Sci. 2018, 39, 3118-3125. [CrossRef]

61. Chen, Y.; Zhao, J.Q.; Tang, D.N.; Tian, X.L.; Wu, Y.G. Heavy metal pollution characteristics and ecological risk of dust fall in Xi'an City. J. Arid Land Resour. Environ. 2017, 31, 154-159. [CrossRef]

62. Li, S.Q.; Yang, J.L.; Run, X.L.; Zhang, G.L. Atmospheric deposition of heavy metals and their impacts on soil environment in typical urban areas of Nanjing. China Environ. Sci. 2014, 34, 22-29. [CrossRef]

(C) 2020 by the authors. Licensee MDPI, Basel, Switzerland. This article is an open access article distributed under the terms and conditions of the Creative Commons Attribution (CC BY) license (http://creativecommons.org/licenses/by/4.0/). 